\title{
A HETERODOX ECONOMICS CRITIQUE OF
}

\section{FINANCIAL LIBERALIZATION}

\author{
Romar CORREA ${ }^{1}$ \\ D. Tripati $R A O^{2}$ \\ DOI: 10.1515/JHEEC-2015-0004
}

\begin{abstract}
We explore a short run structural macroeconomic model with a focus on "the problem of financing economic development" (Kaleçki, 1976). It is demonstrated that banks, in contrast to nonbanks, have a unique role to play in the production and circulation of commodities in a monetary economy. A case is made for class-based policy.
\end{abstract}

Keywords: $\quad$ The monetary circuit.

JEL Classification: B51; E12.

\footnotetext{
${ }^{1}$ Department of Economics, University of Mumbai, Vidyanagari, Mumbai 400 098, INDIA, romarcorrea10@gmail.com, romar77@hotmail.com

2 Business Environment Group, Indian Institute of Management Lucknow, Lucknow 226, 013- Uttar Pradesh, INDIA, dtripatirao@yahoo.com
} 


\section{Introduction}

We critique received wisdom about financial reform. In developing countries, interest rates were kept low in order to induce credit into sectors that were regarded as pivotal from a social and long-term perspective and that would otherwise be deprived. Financial liberalization has meant lifting these caps so that people will be tempted to save more and resources for productive investment would thereby be released. The evidence does not support the neoclassical justification. Empirically, the interest elasticity of savings has always been in question anywhere and the analytical basis for the route from high savings to high investment is far from impeccable. In the case of poor countries, the general level of incomes is so low that sheer survival takes precedence over higherorder motives (Rosenzweig, 2001). Besides, there are strong and volatile inter-annual fluctuations in income because rainfall is unpredictable. Maintaining consumption in the face of low and variable income is the sole occupation of the people in general. With agricultural transformations incomplete, markets guide finance away from agriculture to industry and services. There is an urgent need to open the agrarian question, closed, in particular, after structural adjustment programmes (SAPs) in poor economies. Following Henry Bernstein, the peasantry as a category is problematic and attention must be paid to the social relations of labor (Ellis, 2006). SAPs were introduced into subSaharan Africa in the seventies to rid agriculture there of exploitative parastatals. Accordingly, governments dismantled upper and lower bounds on prices and pushed the economies toward market exchange in order to induce the evolution of competitive private trade in rural areas. The outcome, overall, has been disastrous. Private traders have not rushed into spaces created by fleeing parastatals. The characteristics that remain include a food security crisis which the upheavals of liberalization only worsened. In other words, since the vast majority cannot access markets to purchase food at affordable prices during the lean season, it makes sense to store food. The outcome is limited exchange of food and cash. Actually, the dialectic of State intervention and withdrawal is more subtle (Das, 2007). The State has stepped into agribusiness and supported the production of luxury farm products like flowers and shrimps. At the same time, it cannot ignore smallholder interests. Peasants are part of the commodityproducing process providing capital a market for manufactures. They continue to be an important part of the reserve army providing industrialists a huge workforce.

Secondly, the technological revolution that has swept the financial services industry has led to the conviction that it is unhelpful to think in terms of different financial entities. Banks, for instance, are not regarded as possessing a special status anymore. All financial entities are Universal Banks operating both the in the commodities market as well as in markets for exotic financial products. A pivotal moment in contemporary history, in this regard, is the repeal of the Glass-Steagall Act in 1999 in the USA. The Act of 1933 distinguished between commercial banks and investment banks on the ground 
that their domains of operation should not intersect in the interest of financial stability. In the case of developing countries it is well established that the proximity of banks increases financial savings and crowds out the merchant-money lender route to the provision of insurance. The process of financial intermediation is facilitated. The absence of well-functioning credit markets is reflected in inefficient asset stocks and compositions. The mechanism of financial intermediation is critical in extending credit to informationally-opaque small borrowers (Berger et. al., 2001). The current wave of mergers and acquisitions is likely to create large banks that are adjuncts to capital markets and that are oriented towards large corporate clients. Pure transactions lending describes the relationship between lender and clients where due diligence and contract terms are based on information that is available at the time of signing of the contract. The information set might contain no more than the data that is available in balance sheets. Their remoteness from the particularities of rural markets implies that the abilities of large banks to process local-level information is limited. In the absence of repeated interactions over time, lenders resort to class-based assessment of probabilities rather than case-by-case assessment procedures (Runde, 2002). In the case of small bank lending, on the other hand, information is of a qualitative kind and is garnered from the borrower's suppliers and customers and also from the borrower's interactions with the local community. Relationship banking entails a unique, one-toone, face-to-face interaction between borrower and lender on the basis of which decisions concerning additional funding and monitoring strategies are arrived at. The generation of information is costly and the costs are likely to be passed on to the borrower. The conjecture is that borrowers without a credit history would be willing to bear these costs in order to renegotiate contracts on favorable terms. More to the point in the aftermath of the last financial crisis in the USA, an important element in the frequency of crises is the input-output structure of the banking system, whether extensive branching exists, whether the system consists of a few large banks or many small banks (Gorton, 2012).

Our task is to distinguish the intervention of banks and nonbank financial intermediaries in a classical-Marxian framework. We provide a non neoclassical formalization of these intuitions below.

\section{A commodities circuit}

A common starting point of any structuralist account of a developing economy would be the demarcation of the economy into an industrial and an agricultural sector. For the purposes of the present study, the division cuts across the division of the economy into Departments following Marx's schemes of reproduction (Kaleçki, 1976). Our Sector I includes Marx's Department II producing luxury goods for capitalists, Sector II is Marx's Department III producing basics for workers and Department I producing investment goods is divided into two parts, investment goods produced in Sector I and investment 
goods produced in Sector II. This classification is resorted to in order to make non basics and basics output correspond with the output of Sector I and Sector II respectively. The pricing rule for the industrial sector takes the form:

$$
P_{n}(t)=(1+\tau) w_{n}(t) b_{n}(t)
$$

where $P_{n}$ is Sector I's producer price; $\tau$ is the markup rate; $w_{n}$ is the nominal wage rate and $b$ is the inverse of average labor productivity. Output $X_{n}$ is divided in the familiar way between consumption $C_{n}$ and investment $I_{n}$. Consistent with the division into Departments above is the assumption that the agriculture sector is a food sector providing basics to workers in both sectors. Similarly, the industrial sector output is consumed by capitalists from both sectors. While food is the quintessential basic, it is a catchall for the consumption by workers as might haute cuisine be a metaphor for luxury consumption. Jack Goody (2006) has extended and modified the work of the Marxist historian Gordon Childe in proposing this thesis. He makes the case that the starting point of historical research into either European or Asiatic "exceptionalism", as Marx put it, must lie in the convergences of urban civilizations of the Bronze Age rather than the divergences of the nineteenth century. Both the town and the country were stratified by class based on economic differentiation in the Bronze Age. The continuous series of evidence on towns in Asia indicate that they did not vanish to reappear later as engines of early capitalist enterprise but were vibrant centers of manufacture and exchange. Mass production and an increasing role for finance, as exchange intensified, were not confined to Europe. Under feudalism, the history of urbanization is different outside Europe. The urban economy with its distinction between haute cuisine and basic consumption continuously evolved. Clearly, a class analysis is indispensable.

Modern non neoclassical macro models add a Keynes-Wicksell turn in the assumption that firms make their investment plans on the basis of the divergence between the rate of profit in industry, $r_{n}$, and the real rate of return on bonds, $i-\pi$, with bonds and equities being regarded as perfect substitutes. Distinguishing the agriculture sector by the subscript $a$, excess demand in the non-food sector in nominal terms is given by

$$
\left[P_{n}(t) C_{n}(t)+P_{a}(t) C_{a}(t)+P_{n}(t) I_{n}\left(r_{n}-(i-\pi)\right)\right]-P_{n}(t) X_{n}(t)
$$

where, in an abuse of notation, $C_{n}$ is luxury consumption by urban capitalists and $C_{a}$ is luxury consumption by their rural landlord-capitalist-merchant counterparts. In words, the term on the right-hand side outside the brackets is the total output, in value terms, of the output of Sector I. The demands of it are depicted in the square bracket and consist of two parts; one part, subscripted by $n$, is the sum of consumption and investment demands by the sector (the time argument in the case of the investment function is implicit), the other, subscripted by $a$ is the demand for luxury commodities coming from Sector II.

The agricultural sector is assumed to be flexprice and we assume, without loss of generality, that financial portfolio choices are unavailable to the kulaks. Investment in the sector depends only on the rate of profit there. Excess demand in Sector II is

$$
\left[w_{n}(t) L_{n}(t)+w_{a}(t) L_{a}(t)+P_{a}(t) I_{a}\left(r_{a}\right)\right]-P_{a}(t) X_{a}(t)
$$


where $w_{i} L_{i}$ is the wage bill in sector $i$. Once more, the term on the right-hand side outside the brackets is the total output, in price terms, of the output of Sector II. The demands of it are depicted in the square bracket and consist of two parts; one part, subscripted by $a$, is the sum of consumption and investment demands by the sector (the time argument in the case of the investment function, again, is implicit), the other, subscripted by $n$ is the demand for luxury commodities coming from Sector II.

The traditional Keynesian adjustment process posits an inversion of the Walrasian tâtonnement adjustment process. Quantities are assumed to adjust to quantity discrepancies on the assumption of chronic excess capacity. We have

$$
\frac{d X_{n}}{d t}=\left[P_{n}(t) C_{n}(t)+P_{a}(t) C_{a}(t)+P_{n}(t)\left(I_{n}\left(r_{n}-(i-\pi)\right)-P_{n}(t) X_{n}(t)\right]\right.
$$

The agricultural sector, on the other hand, is resource-constrained. An increase in the supply of food can only come from investment activities like irrigation works and so on. Prices take on the brunt of adjustment for the agricultural sector. In the situation of excess demand described above,

$$
\frac{d P_{a}}{d t}=\left[w_{n}(t) L_{n}(t)+w_{a}(t) L_{a}(t)+P_{a}(t) I_{a}\left(r_{a}\right)-P_{a}(t) X_{a}(t)\right]
$$

The stability of the homogenous part of the system is determined by following matrix

$$
\left(\begin{array}{cc}
-P_{n} & C_{a} \\
0 & I_{a}-X_{a}
\end{array}\right)
$$

Call the matrix A and determinant and trace are denoted by the usual det and $\mathrm{tr}$ respectively. Now, since, by definition, $I_{a}-X_{a}<0$, $\operatorname{det} \mathrm{A}>0$, and the other standard condition for stability, $\operatorname{tr} A<0$, is naturally met. The more stringent requirements to prevent bifurcations are the following (Medio \& Lines, 2001).

$$
\begin{gathered}
1+\operatorname{tr} A+\operatorname{det} A>0 \\
1-\operatorname{tr} A+\operatorname{det} A>0 \\
1-\operatorname{det} A>0
\end{gathered}
$$

The inequalities, in sum, neatly encapsulate a tension in the debate on the optimal route to capitalism (Byres, 1996). A high value of the single north-west element is sufficient for stability and validates the Preobrazhensky thesis underscoring the necessity of the terms of trade to move against agriculture in order to facilitate accumulation outside agriculture. The function of agriculture is not only to generate a real surplus but also a financial surplus. The surplus of interest is the marketed surplus which represents a 'command over real resources' which can be transferred from agriculture. In addition, small farmers are net buyers of food. Kaleçki assumed that there would be no inflationary price increases of necessities, particularly of staple foods. Any policy stance of that kind "militates against any sense of social justice" (Kaleçki, 1976, p.18). It is necessary, then, to expand agricultural output in the short run $\left(X_{a}\right.$ in the south-east corner of the matrix). The higher supply of food will enable the system to feed those who transfer to non-agricultural output. A substantial increase in agricultural output is feasible in a short period of time without heavy investment by the introduction of small- 
scale irrigation projects, double-cropping and the like. Any energies along these lines are hampered by class divisions in the countryside. The mass of small peasants is bonded to merchants and moneylenders. Farms operate under a system of disguised tenancy without security of tenure. Government polices must be targeted at breaking these institutional shackles. Service cooperatives could be set up for the purpose of credit disbursement and sale of produce. It is worth noting, for completeness, that addressing effective demand failure through an increase in the consumption of luxury commodities by the landed aristocracy, (the north-east corner of the box), is irrelevant to the stability of the model. Indeed, it is the task of Marxian political economy to critique growth models which are oriented towards the consumption of non-basics (Perraton, 2007). The task is to articulate conditions under which real wages can grow consistent with the growth of productivity. The market-led model of land reform has been unsuccessful in pushing a productivity-led redistribution of wealth in contrast to the State-led model (Borras \& McKinley, 2006). There can be no overall growth without accelerated rural development and the latter cannot result without serious land reform. The efficiency of the post-reform agrarian system in the State-led model which includes Japan, The Republics of Korea and Taiwan, Bolivia, Chile, Cuba, Mexico, was obtained by massive complementary public investments, credit and technical assistance.

At the same time, a critique of the Prussian road or what Lenin called 'capitalism from above' is implied, according to which landlords are the motor to capitalist transformation. One regressive vertex of that path has been the continuous impoverishment of the peasantry resulting in a significantly shrunken home market. The impact on capitalist industry, as well, cannot be salutary. Department II branches (in the traditional sense) would be constricted by the narrow home market. Lenin was concerned with the sluggish mechanization of agriculture. The consequence was a constricted market, once again, for the output of capitalist manufacturing industry especially the products of Department I branches (in the traditional sense) like chemical fertilisers, farm implements and machinery.

Lenin made the case for the American path or 'capitalism from below'. The dynamic here is from a differentiating peasantry with vigorous class-for-itself action pursued by rich peasants and capitalist farmers. As the differentiation proceeds, the capital-labour relation evolves. The transition is clearly plausible in a milieu where the landlord class is weak but is not ruled out in a regime where the class is strong, provided certain conditions are in place. The American path was progressive in two ways (Byres, 1996). The forces of production were developing in the countryside. Modern inputs were being applied and mechanization was proceeding apace. Semi-feudal relations of production were not fetters. Secondly, the path entailed a massive growth of the home market. Department I industries supplying agricultural inputs were faced with an expanding home market. In addition, the rise in the standard of living of the peasantry provided an impetus to Department II industry. Such a transition can be facilitated by dwindling numbers of the landlord classes along with dismantling the state structures and the class configurations that they represent. The requirement is heroic: a reconstituted, strong 
State with the capacity to engage with the power of an entrenched landlord class. For the same reason, the outcome is unlikely to be seen in developing countries, given the ambiguous nature of what Kaleçki called "intermediate regimes" there. The indispensability of land reform cannot be emphasized enough, for otherwise, rising incomes of producers of food would be absorbed in higher rents and debt payments, increasing the demand for non-basics among merchants, moneylenders and landowners (Toporowski, 2006). In our times, "relentless pressure from below" has worked in Mexico in the 1930s, Kerala in India in the 1960s and 1970s, and in Chile during the early 1970s (Borras \& McKinley, 2006). The rural poor consisted of a thick spectrum of landless peasants, farm workers, small farmers, and indigenous peasants and organized, independent of the tutelage of the State.

We proceed to consider the implications of lifting a regime of financial repression. How does a unit change in the interest rate impact on prices? Under the assumption of a regime of chronic excess demand, $C_{n}+I_{n}-X_{n}>0$, in real terms, we have

$$
\frac{d P_{n}}{d i}=\frac{-\frac{d I_{n}}{d i}}{C_{n}+I_{n}-X_{n}} \geq 0
$$

An increase in the interest rate raises the price of non basics. In standard one-sector models, $P_{n}$ would be the general price level. In like manner, what is the impact on output of a flexible interest rate?

$$
\frac{d X_{n}}{d i}=\frac{-\frac{d I_{n}}{d i}}{-P_{n}} \leq 0
$$

An increase in the interest rate reduces the output of non basics. Once again, in a onesector model $X_{n}$ would be output. In familiar terms, the outcome is stagflation (Weller, 2001). The consequences for agriculture are no less deleterious. It is unnecessary to posit a regime of excess demand to conclude that the impact of rising interest rates is a rise in the price of agricultural output.

$$
\frac{d P_{a}}{d i}=\frac{-\frac{d I_{n}}{d i}}{C_{a}} \geq 0
$$

A final consequence to consider is the impact of the interest rate on the markup. The result is once again familiar. The degree of monopoly increases. A regime of excess demand benefits the capitalist class.

$$
\frac{d \tau}{d i}=\frac{-\frac{d I_{n}}{d i}}{\frac{d P_{n}}{d i}\left(C_{n}+I_{n}-X_{n}\right)} \geq 0
$$

The signs of the derivatives are a corollary of the empirical observation that financial liberalization in developing countries has had an adverse impact especially on farmers and workers, including during so-called financial booms (Ghosh, 2005). The proposition 
is not revolutionary. From the highest positions of establishment orthodoxy comes the theorem, derived from exacting statistical testing, that inflation, inequality, and class conflict are correlated (Crowe, 2006). The inflation tax is regressive not the least because workers and capitalists have differing access to inflation-proof assets. Developing countries are more unequal and therefore experience higher inflation. The class nature of the political system and inequality interact to generate inflation.

Our outcomes are perfectly consistent with the unity of Keynesian, structuralist, and Marxist models of growth and distribution (Foley \& Taylor, 2006). The common core resides in the study of the distribution of national income between workers and capitalists; the eschewing of model closures that imply full employment of the labor force; differential modeling of the consumption and savings decisions of workers and capitalists; the adoption of an investment demand function independent of savings decisions; and a separate treatment of the firm as an agent independent of its owner households. With Marx, as with Kaleçki later, less-than-full utilization of capacity is the norm in advanced capitalism. Variations in investment will be met with variations in capacity utilization with no effect on distribution. Income shares, on the other hand, are determined by the principle of markup pricing on unit labor costs in noncompetitive commodity markets. The markup, in its turn, is determined by the degree of monopoly in the goods market and by the class struggle in the labor market.

The task ahead is further enlightened the interplay between the real and financial components of the capitalist system. We suggest below that the circuit approach to monetary macroeconomics, active in France and Italy, is a natural complement to the real circuit enunciated here. Comprehensive treatments of the former will be found in Cencini (2005), of the latter in Graziani (2003).

\section{The credit circuit}

With Marx as well as circuit theory, the capital-labor relation requires credit money because the purchase of labor is logically prior to the production of commodities as well as the production of a money commodity. Labor power as an input to capitalist production is a commodity and, as such, has been bought and sold in the sphere of circulation prior to production, at a given price (Moseley, 2008). Indeed, according to recent scholarship, the classical theory of value can be interpreted as a 'monetary theory of value' and the theory of money as a 'credit theory of money' (Cavalieri, 2013; Hein, 2008). The separation between values and prices has transformed into structurally integrated systems. Wages are paid in money and can access a range of basics. In Capital Volume I, Marx demonstrates the necessity of a universal equivalent for capitalist production. Since money has to represent 'abstract labor', its value cannot be determined by the quantity of 'concrete labor' expended in the production of a certain money commodity. In that case, Marx's theory of money is freed of theoretical metallism. Rather, money is the socially acceptable representation of the universal equivalent which has to be underpinned by social institutions. The modern credit system, which is 
founded on promises to pay, conforms nicely. The practice of circuit theory is to reason in terms of moments. Scrupulous accounting principles connect the moments. To positive items must correspond negative items of equal magnitude. For Marx as well, the price of labor power is identically equal to the variable capital that has been advanced to purchase it. Recent internal critiques of Marx's circulation schemes are founded on the discipline of accounting (Cartelier, 2007). The notion is that the form of circulation corresponding to a commodity division of labor is $\mathrm{M}-\mathrm{C}-\mathrm{M}$ (with $\mathrm{M}=\mathrm{M}$ ). The difference between simple commodity production and a capitalist economy is founded on a wage relationship in the latter with a derived labor-money-commodity (L-M-C) circulation. The argument hinges on Marx's emphasis on both the independence of activities and the fact that each producer acts on her own account. The latter implies that each individual is in command of her own process of production, purchasing necessary inputs and the means of reproduction. The former means that commodity production is for sale. A consequence is that producers can only be part of a commodity division of labor if they own the means of payment permitting them to produce autonomously of the decisions of others. This is M-C of M-C-M. Producers decide anarchically to spend a certain fraction of money. These expenditures might be displayed along the rows of a payments matrix, each producer associated with a row. But the social accounting matrix imposes an interdependence among the producers. They must validate their activity by selling their output. They cannot earn, from the market, less than they have spent. The constraint is C-M of M-C-M. One producer's receipts are another producer's expenditures. Receipts and expenditures are simultaneously determined. The circuit closes when the initial disbursement of $\mathrm{M}$ by banks is returned to them by producers.

When individuals who constitute the commodity division of activities succeed in making those who are excluded because they do not possess the means of payment join them, the former become entrepreneurs, the latter workers. Workers spend a proportion of their incomes. While they are free to decide the fraction of income saved, they are not in command of their resources. Thus, L-M-C is a derivative of the circulation of commodities. Workers have nothing to sell but their labor power because they are neither private nor independent. They acquire commodities but these commodities are simply use values. The consumption bundle of workers does not enter the technique of production. Businessmen consider money wages as a cost not as an expenditure outlet. On the other hand, in the case of simple commodity production, in equilibrium the consumption of the producer is a socially necessary as other material inputs. It is only in capitalist society with M-C-M buttressed by L-M-C, that net value may appear.

In a monetary production economy, the production and circulation of commodities between the Departments is mediated by banks. The role of banks is unique in that they, and only they, can lend out claims on their own debt (Bossone, 2001). Only banks possess the ability to add to the existing stock of money by lending promises to pay. Thereby the total credit in the economy can exceed what is possible if credit has to be fully recovered. Banks create money and generate purchasing power in anticipation of the production of commodities. In Capital Vol.III, as well, Marx does not assume that the 
credit supply of commercial banks is limited by private savings but shows that commercial banks can create credit without limits which circulates as credit money.

According to the circuit approach applied to our framework, the sequence consists of three points: 1. the creation, 2. transfer and 3. destruction of income. An illustration on the lines of Bossone in terms of the model sketched in the previous section is provided in an Appendix. The italicized items are the balancing counterparts, in the balance sheet sense, of identical primary entries whose numbers depict the three moments defined above. At the start of the circuit banks negotiate with capitalists (industrial and agricultural) the conditions for working capital loans, $w_{a} L_{a}$ and $w_{n} L_{n}$, respectively. The banks credit the deposit accounts of the capitalists with the loan amounts, denoted by the italicized entries, loan claims and loan deposits, respectively, in both Departments. The firms produce, using the loans to pay wages to workers (industrial and agricultural). Entries numbered 2 in the flow of funds distinguish this moment. Deposits are transferred from the bank accounts of the capitalists to the accounts of the workers. The latter is wages in the balance sheet of workers matched by the italicized wage payments in the balance sheets of the former. At the second point of the sequence, workers spend their incomes on basics. Capitalists spend their incomes on non basics. Sales across classes and commodities, depicted by $3^{\prime}$ and $3^{\prime \prime}$ are identically equal to purchases 3 . The circuit ends when capitalists use the proceeds from their sales to discharge their debt to the banks. The money that was created is destroyed. Banks do not create value. The freshly issued money assumes value only in the process of production. All money transfers and payments for commodities and labor services take place through deposit transfers across bank accounts. No cash circulates. At circuit end capitalists must secure enough money to pay off their initial debt. No transfer of real resources is entailed from them to the banking system. In case of the example worked out in the Appendix, adding up over the two sides of the balance sheets of capitalists, their "financial obligations" to the banks equals their "deposits with the bank", both being equal to $w_{a} L_{a}+w_{n} L_{n}$. Money disappears in equilibrium as a shadow of the goods and services it symbolizes (Shubik, 2006).

The credit system introduced above works on a hierarchy of promises to pay with stronger social validation and liquidity beginning with the base of bank-borrower relationships. Graziani closely works out the details of a transaction between two parties being effected by means of a promise to pay of a third party and so on. The pyramid peaks with fiat money because only Central Banks can guarantee final payment (Thornton, 2008). Other scholars, as well, work out the close connection between the bank issue of money to finance the production and circulation of commodities and sovereign control of the mint (Goodhart, 2004; Wray, 2006). Before the evolution of Central Banks, countries operated within low-level equilibrium traps. Production and exchange was rudimentary and fragmented, mediated by local moneys. It is only when the unifying force exercised by an instrument that bore the imprimatur of the State evolved, that the capitalist mode of production could grow in leaps and bounds. Fiat money rounded up private monies, destroyed the antimonies of time and space, and 
enabled a manifold increase in the quantity and variety of goods and services. Commercial banks, again, are not intermediaries between borrowers and lenders but rather permit creditors and debtors to clear accounts with a third party. The market is not a place where commodities are exchanged but is a clearing house for debts and credits. Banks deliver this service. The Central Bank, after all, is a member of the club of banks. Historically, some banks were accorded this special status because their notes assumed a special quality. The agents who control the money and credit structures can influence the constraints that are either slack or have positive shadow prices (Shubik, 2006). The decision to change the intensity of the constraints lie with the borrowers and lenders and their assessments of risk. The collapse of the link between Central and commercial banks, according to the Chartalists, would lead to the degrading of the mint and the collapse into barter. The defining character, according to them, is the power of the State to levy taxes. In the first place, absent money, taxes could only be imposed on commodities, since only they can be delivered. If taxes were paid in goods or labor, the balance of goods and services obtained would not be the quantum required for public sector expenditure. Money, thus, reduces the transaction costs of governments. For our purposes, it is worth noting that the ability to impose taxes payable only in money has been used on numerous occasions in colonial history to coerce taxpayers out of a nonmonetary subsistence economy into a cash economy. The receipt of revenue was often a subsidiary motive. In other words, public and private finance are organically related (Merton \& Bodie, 2007).

Our categories, so far, only include consumer goods markets and firms producing consumer goods. In an extended Marxist circuit of capital, the capitalist class subdivides into money capitalists and functioning capitalists. The expansion of the credit system requires the establishment of interest-bearing capital with the interest rate as a claim on a portion of the surplus value produced by productive labor. In what will be called the second moment of circuit theory, capitalist production process requires money advances. Each quantum of such money assumes the role of interest-bearing capital which can be sold for 'interest'. Functioning capitalists are willing to borrow from money capitalists and pay interest because money has the potential to generate money profits. In order for contracts to be signed, the Keynes-Wicksell criterion must be met. The rate of profit has to exceed the rate of interest. Thus, the interest rate in Marx's schema is a monetary category determined by the relative powers of industrial and money capital. Reverting to circuit theory, households, typically, will not invest their entire incomes on consumption but will avail of opportunities provided by financial markets. At least we can assume that the propensity to save by the capitalist class exceeds that of the working class. The savings are availed of by investing enterprises which use these resources to purchase the output of capital goods-producing firms. In identical fashion, the conclusion of this parallel stage 2 ends with the sales of their output by firms in capital goods markets. For the French school following Bernard Schmitt and Alvaro Cencini, accounting purity must be maintained and the activity of banks in the first moment must not be confused with the activity of nonbank financial 
intermediaries (NBFIs) in the second moment. The recording of production, sales and profits must be kept separate.

The problem, eloquently articulated by Keynes, is that fundamental uncertainty underlies the decision to make long-term investments. Risk-management techniques he would describe as no more than "pretty, polite techniques" to deal with the future. "We simply do not know". The temptation presses on private savers and investors to devise contracts, beginning with first-order correspondences with the underlying real assets but then moving to complex, contingent, claims where the connection with the underlying assets is lost. The best of intellectual resources are at work today in writing arcane models for packaging and repackaging assets far removed from the informational idiosyncrasies of particular financial entities. Contemporary financialization attenuates the circuit of the flow of capital goods and services by the focus on short-term gains at the expense of what might be termed the long-term social surplus (Blackburn, 2006). Balanced multi-Departmental growth requires infrastructure and investment in an educated working class, a strategy that does not pay off for decades. The roller coaster stock market ride of the nineteen eighties and nineties lacked credibility and foresight, the hallmark of the plan of Keynes and other architects of the postwar boom. Developing countries have not been exempt. In a panel data study of countries including Argentina, Mexico and Turkey, financial liberalization is shown to channel real savings into financial churning rather than long-term capital investments (Femir, 2007). Thus, financialization is intimately linked with deindustrialization. Financial innovations carry the further embellishment that, unlike developments in manufacturing and agriculture, they enrich a negligible portion of the population and cannot form part of a broad-based plan to increase demand. The vaunted superior risk-management techniques referred to have been of virtually no consequence for production. Financial profits, instead, have been ploughed back to increase the turnover of non basics. In Marxist terms, the current phase of the division of labor is accompanied by the crisis of the law of value-labor and the return of mercantile and financial mechanisms of accumulation that is reminiscent of the formal subsumption of labor under capitalism (Vercellone, 2008). In an economy based on the production of knowledge by means of knowledge, the directly necessary labour time for production is reduced and the monetary value of production falls sharply. As a result, in order to keep the level of exchange value in place in order to guarantee profits, capital is led to devise mechanisms of revenue extraction based on the rarefaction of supply. Marxist scholars summarize the potential for crisis in the M-C-M (Demir, 2007) or M-C-M' (Vercellone, 2007) general formula. In both cases, $M$ or $\mathrm{M}^{\prime}$ denotes flexibility and freedom of choice. $\mathrm{C}$ is an interruption denoting materialization and rigidity. Capital would rather be in liquid form.

\section{The possibility of crisis}

The bifurcation in the second moment, when nonbanks intermediate between savers and investing enterprises, is likely to be an arena of financial innovation as all parties 
concerned seek to grapple with Keynes' dark forces of time and ignorance. Academia and Wall Street have joined forces as Nobel laureates in economics translate the best of finance scholarship and become hedge fund managers. Even so, none but a handful can understand some of the modern esoteric offerings. Many observers have argued that the present conjuncture, money manager capitalism, is a special phase in the evolution of capitalism running from commercial, financial, and managerial (Whalen, 2008; Wray, 2008). The rallying point is securitization which is the pooling of assets to serve as collateral against issued securities. For the purposes of our discussion it is important to note that the phenomenon runs in the opposite direction of banking in which loans are granted against deposits held. Relationship banking is based on the characteristics of the borrower which include income and ability to repay while the new models are backward-looking regarding default rates of similar borrowers. The concatenation of circumstances has been described as cognitive capitalism and was anticipated by Marx in Capital Volume III and Grundrisse (Vercellone, 2007, 2008). It is marked by the hegemony of knowledge. The genesis was recorded in Capital Volume I. The struggle associated with the legal reduction of the working day was linked to a general struggle for the socialization of knowledge. The reduction of direct labor time necessary for production permits leisure for education. The relation of subordination of the living knowledge embodied in labor power to the dead labor incorporated in fixed capital is overturned. According to Marx, capital ownership was following a path akin to ground rent in the shift from feudalism to capitalism. Unlike ground rent, however, capitalist rent is a pure relation of distribution because it is not connected with the process of production. Marx distinguished between the passivity of the ownership of capital and the active character of the performing capital that, as a consequence of the separation of the ownership from control, becomes increasingly embodied in the money manager where the functions of leadership and exploitation of labor take on the appearance of labor practicing conceptual tasks in production.

In sum, financial hyperactivity lowers the virtuous portion of the second moment and narrows the basis for future elaborations of the first moment. Still, this does not mean structural disjuncture. NBFIs cannot be prevented from innovating. The job is to cocoon the banks-basic production subsystem from financial meltdowns. The possibility of a crisis arises when Moments I and II mingle, when the distinct roles played by banks and financial intermediaries is blurred (Goodhart, 2008; Wray, 2008). Banks facing extinction in the form of dwindling margins have entered the "originate and distribute" (another word for securitization) business. In the USA, around 2000, banks originated business in the real estate market in the form of residential mortgages. They then bundled these mortgages together and sold off the packages usually to hedge funds. This led to a disintermediation of assets off the balance sheets of banks. Recall the contrast with the defining character of banks which, for decades, funded their assets through retail deposits. Banks in the sixties and seventies were concerned with the quality of credit assessment and monitoring of the borrowers' actions during the tenure of loans. In recent times, there has been a greater reliance on wholesale funding and the short 
end of the credit market. Earlier, while in principle deposits were withdrawable on demand, assets were relatively stable even when the market reputation of the bank in which they were placed was in question. Now, the liabilities are of a maturity of one to six months. In sum, liquidity has declined dramatically calling for frequent Central Bank bailouts.

\section{Class-based policy}

Keynes, in the Treasury memoranda of 1943-1944, proposed the "socialization of investment" as a strategy to address the problem of unknowledge that plagues the inducement to investment (Seccareccia, 1994; Smithin, 1989). Through the thirties and the forties, Keynes supported the establishment of a National Investment Board. The mandate of the board was to move the economy towards full employment by regulating the aggregate flow of investment expenditures through the control of long-term financing. He did not advocate fiscal fine-tuning or deficit financing. Keynes made a distinction between the ordinary or current budget and the capital budget with the former balanced or in surplus in the short run. The distinction between investment and capital spending and consumption or current spending has to be scrupulously maintained. A policy of direct public investment, if accounted for by the capital budget would, other things being equal, generate persistent surpluses in the ordinary budget. Thereby deadweight debt would be gradually replaced by productive or semiproductive debt. The State was to use its surplus not to extinguish its debts but to expand capital expenditures further. Deficit financing of capital spending is politically more defensible than deficit financing of undifferentiated State expenditure. Productive State investment would be immune to the charge of crowding out which might be made of deficit-financed current spending. Specifically, the expectation was that two-thirds to a third of total investment would be directly influenced by semi-public bodies whose activities would not be antithetical to the traditional 'motive of private exchange' but would also include 'technical social' motives that would justify investment in social infrastructure. The socialization of investment would reduce interest rates through capital saturation. It is clear that, nomenclature notwithstanding, this principle of capital budgeting has little to do with the State ownership of the means of production. The proposal has more to do with the composition of government expenditure than the prognosis that a growing proportion of total investment expenditures in the economy would become socialized.

Secondly, Bossone and Sarr (2005) have imaginatively extended circuit theory to the plight of desperately poor economies. The proposal is to construct a firewall between the lending and the deposit-creating functions of banks. In a parallel first step 1, DepositCreating Institutions (DCIs) would collect non-interest-bearing deposits and would distribute money on a non-lending basis, that is, with no condition to restitution. Their liabilities would be backed by Central Bank money. Every deposit balance would augmented by a proportion of the depositor's own holdings calculated over a reference 
period. DCIs would not extend credit but would earn revenue from fees charged for payments services. They would not be permitted to distribute their liquidity to capitalists or non DCI intermediaries. The latter would fund their assets exclusively with non debt instruments. The proposal is distinct from the institution of narrow banking which is concerned with deposit acceptance (Bossone, 2002). At the same time, there are some resemblances. In both instances, the objective is to ensure the complete integrity of the money supply process and both innovations involve a firewall. However, narrow banks would need some critical scale to operate effectively. Along with the high standardization of narrow bank products, narrow banking is ideally a natural monopoly. In that case, a narrow bank could as well be the Central Bank. Besides, narrow banks could be prone to shortages of reserves because of the following dilemma: narrow banks would need eligible paper to raise reserves but they cannot buy the paper because they do not have the reserves. In contrast, banks in the monetary circuit create the deposits they require (although this gives rise to an indeterminacy to be addressed below). Circuit theorists are fond of reasoning in terms of one bank and one money in which case we have a Central Bank and fiat money. By way of real-world resonance, ringfencing of retail banks in the UK is on a timetable. All deposit-taking and short-term lending must be docked in a separately-capitalized subsidiary. The proposal is due to be put into law by 2013 with implementation by 2018. The impulse is a post-USA-financial crisis world. For instance, Paul Volcker has recommended the breakdown of "too big to fail" (TBTP) banks into smaller entities (Volcker, 2012). We also recall the distinction between risk and uncertainty, the latter not being amenable to capture by the calculus of probability. Thus, the economics of asymmetric information is irrelevant and the theory of implicit contracts and mechanism design cannot help. At stake here is the absence of trust (Bossone, 2004). The concept includes an agent's assessment that her counterparty to a contract would make all reasonable efforts to deliver on long-term contract obligations. Central Banks are best positioned to generate trust. Banks create the economy's medium of exchange while nonbank financial intermediaries transfer savings from surplus units to deficit units. Under the Bossone-Sarr scheme, these financial institutions would operate under securities firm regulation. Their innovative impulses would not be impaired. Their non-monetary financial activities would be backed by nonguaranteed funds and they would be allowed to fail.

The motive force behind the scheme is to kickstart the circuit from a position of near inactivity. The money would be disbursed to workers. The demand for food, clothing, and housing would rise. Production and production finance for these goods would be stimulated. Higher output would mean greater capital accumulation and so on in second and higher order effects. The balance-sheet of the circuitistes would determine the amount to be distributed. In other words, denoting the money stock by $M$, we have

$$
M=w_{a} L_{a}+w_{n} L_{n}
$$

The State must ensure that the growth of $M$ is consistent with the production of basics. The money distributed to workers would allow firms to capture liquidity as revenues. Capitalists would use non DCIs to purchase inputs and start production. The Central 
Bank would issue reserves and ensure that the reserves stock is consistent with its projection of the production of basics. Reserve injections and withdrawals would be effected through open market operations with non DCI intermediaries. Recent scholarship supports our thesis (Duprey, 2013). Individual bank balance sheet data over 1990-2010 for 93 countries covering 459 public banks shows that public bank lending decreases significantly less during economic downturns. Their balance sheets are less vulnerable, their access to stable financing sources superior, and they are more inclined to extend loan maturities. In general, public banks provide smaller loans to new customers even at the peak of the cycle and cut back less on existing loan relationships during downturns due to a limited dependence on short-term finance and secure public support.

\section{Conclusion}

The production of basics by means of basics is financed by banks. The Central Bank, as an important organ of the State, is able to generate and retain confidence in the monetary circuit. The flow of new capital goods, on the other hand, depends on the expectations of the future which are not stationary. The State, with its non-private decision-making processes and time horizons, can effect long-term investments in basics investment. Secondly, the time-honored practice of building firewalls between different financial entities must be restored. In our case, the money-basics subsystem and hedge fundnonbasics subsystem must be separated. The dizzying pace of financial innovation can continue without brakes in the latter case, throwing up winners and losers. Recalling Keynes in conclusion, speculation "could do no harm as bubbles on a steady stream of enterprise". However, the situation "is serious when enterprise becomes the bubble on a steady stream of speculation".

\section{References}

Afonso, A \& Furceri, D 2010, 'Government size, composition, volatility and economic growth', European Journal of Political Economy vol. 26, no. pp. 517-532.

Berger, AN, Klapper, FL \& Udell, GF 2001, 'The ability of banks to lend to informationally opaque small businesses', Journal of Banking and Finance, vol. 25, no. 3, pp. 21272167.

Blackburn, R 2006, 'Finance and the Fourth Dimension', New Left Review, vol.39, pp. 3970.

Borras Jr, SM \& McKinley, T 2006, 'The Unresolved Land Reform Debate: Beyond StateLed or Market-Led Models', UNDP International Poverty Research Centre, Policy Research Brief No.2. 
Bossone, B 2001, 'Do banks have a future? A study on banking and finance as we move into the third millenium', Journal of Banking and Finance, vol. 25, no. 12, pp. 2239-2276.

*** 2002, 'Should Banks be Narrowed?', Levy Economics Institute Working Paper 354.

*** 2004, 'Financial Development and Industrial Capital Accumulation', World Bank Policy Research Working Paper No. 2201.

Bossone, B \& Sarr, A 2005, 'Non-Credit Money to Fight Poverty', in Fontana, G. \& Realfonzo, R (eds.), The Monetary Theory of Production, Palgrave, Macmillan London, pp. 187-201.

Byres, T 1996, Capitalism from above and Capitalism from below, Macmillan Press, London.

Cartelier, J 2007, 'The hypostasis of money', Cambridge Journal of Economics, vol. 31, no. 2, pp. 217-233.

Cavalieri, D 2013, 'A theory of capital as value in progress', MPRA paper No.47197, May 2013

Cencini, A 2005, Macroeconomic Foundations of Macroeconomics, Routledge, London.

Crowe, C 2006, 'Inflation, Inequality, and Social Conflict', IMF Working Paper/06/158

Das, RC 2007, 'Introduction: Peasant, State and Class', The Journal of Peasant Studies, vol.34, nos. 3\&4, pp. 351-370.

Duprey, T 2013, 'Bank Ownership and Credit Cycle: the lower sensitivity of public bank lending to the business cycle', Paris School of Economics Working Paper 2013-5

Ellis, F 2006, 'Agrarian Change and Rising Vulnerability in Rural Sub-Saharan Africa', New Political Economy, vol.11, no.3, pp. 387-397.

Femir, F 2007, 'The Rise of Rentier Capitalism and the Financialization of Real Secgors in Developing Countries', Review of Radical Political Economics, vol.39, no.3, 351359.

Foley, D \& Taylor, L 2006, 'A heterodox growth and distribution model', in N. Salvadori (eds.) Economic Growth and Distribution, Cheltenham: Edward Elgar, pp. 75-99.

Ghosh, J 2005, 'The Economic and Social Effects of Financial Liberalization: A Primer for Developing Countries', United Nations, Department of Economic and Social Affairs Working Paper No.4

Goodhart, CAE 2004, 'Financial Stability and Economic Growth: Explaining the links', in Goodhart, CAE (ed.), Money, Stability and Growth, Palgrave, London, pp. 183-206.

*** 2008, 'The background to the 2007 financial crisis', Journal of International Economics and Economic Policy, vol.14, no. 4, pp. 331-346.

Goody, J 2006, 'Gordon Childe, the Urban Revolution, and the Haute Cuisine: An Anthrpro-archaeological View of Modern History', Comparative Studies in Society and History, vol.48, no.3, 503-519.

Gorton, G, 2012, 'Some reflections on the recent financial crisis', NBER Working Paper 18397

Graziani, A 2003, The Monetary Theory of Production, Cambridge University Press, Cambridge. 
Hein, E 2008, Money, Distribution, Conflict and Capital Accumulation, Palgrave Macmillan, Hampshire.

Kaleçki, M 1976, Essays on Developing Economies, The Harvester Press, Sussex.

Medio, A \& Lines, M 2001, Nonlinear dynamics: a primer, Cambridge University Press, Cambridge.

Merton, RC \& Brodie, Z 2007, 'The Design of Financial Systems: Towards a Synthesis of Function and Structure', NBER Working Paper 10620

Moseley, F 2008, 'The "Macro-monetary" Interpretation of Marx's Theory: A Reply to Rvagnani's Critique', Review of Radical Political Economics, vol. 40, no. 1, pp. 107118.

Perraton, J 2007, 'Evaluating Marxian contributions to development economics', Journal of Economic Methodology, vol. 14, no. 1, pp. 27-46.

Rosenzweig, MR 2001,'Savings Behaviour in Low-Income Countries', Oxford Review of Economic Policy, vol.17, no. 1, pp. 40-54.

Runde, J 2002, 'Assessing creditworthiness and small-firm bank lending', in Arestis, P, Desai. M \& Dow, S (eds.), Methodology, Microeconomics and Keynes, Routledge, London, pp. 203-214.

Seccareccia, M 1994, 'Socialization of investment', in Arestis, P \& Sawyer, M (eds.), The Elgar Companion to Radical Political Economy, Edward Elgar, Aldershot, pp. 375380.

Smithin, J 1989, 'The Composition of Government Expenditure and the Effectiveness of Fiscal Policy', in Pheby, J (ed.), New Directions in Post-Keynesian Economics, Aldershot,

Edward Elgar, pp. 209-227.

Shubik, M 2006, 'Theory of Money and Financial Institutions', Cowles Foundation Discussion Paper No.1572

Thornton, DL 2008, 'Monetary Policy: Why Money Matters and Interest Rates Don't', Federal Reserve Bank of St. Louis Working Paper 2008-011A

Toporowski, J 2006, 'Michal Kalecki', in Clark, DA (ed.), The Elgar Companion to Development Studies, Cheltenham, Edward Elgar, pp. 304-308.

Vercellone, C 2007, 'From Formal Subsumption to General Intellect: Elements for a Marxist Reading of the Thesis of Cognitive Capitalism', Historical Materialism, vol.15, pp.13-36.

*** 2008, 'The new articulation of wages, rent and profits in cognitive capitalism', Queen Mary University School of Business and Management Working Paper No.2

Volcker, P 2012, Unfinished Business in Financial Reform, International Finance, vol.15, no.1, pp. 125-135.

Weller, CE 2001, 'Financial Crises After Financial Liberalization: Exceptional Circumstances or Structural Weakness?', Journal of Development Studies, vol.38, no. 1, pp. 98-127.

Whalen, C 2008, 'Understanding the Credit Crunch as a Minsky Moment ', Challenge, vol.51, no.1, pp. 91-109. 
Wray, R 2006, 'Banking, Finance, and Money: A Socioeconomic Approach', Jerome Levy Institute Working Paper No. 459

*** 2008, 'Financial Markets Meltdown: What Can We Learn from Minsky?', The Levy Institute of Bard College, Public Policy Brief No. 94

\section{Appendix}

\section{The Monetary Circuit}

A. BASICS

AGRICULTURAL CAPITALIST (AC)

\begin{tabular}{|l|l|l|l|}
\hline Deposit with bank & & Financial Obligations & \\
1 + loan deposit & $+w_{a} L_{a}$ & $1+$ loan debt to bank & $+W_{a} L_{a}$ \\
2 - wage payments & $-W_{a} L_{a}$ & & \\
3 - payments to IC & $-P_{a} C_{a}$ & & \\
$3^{\prime}+$ sales to AW & $+W_{a} L_{a}$ & & \\
$3^{\prime \prime}+$ sales to IW & $+w_{n} L_{n}$ & & \\
\hline
\end{tabular}

AGRICULTURAL WORKER (AW)

\begin{tabular}{l|l}
\hline Deposit with bank & 0 \\
2 + wages from $A C$ & $+w_{a} L_{a}$ \\
3 - payments to $A C$ & $-W_{a} L_{a}$
\end{tabular}


B. FINANCIAL INTERMEDIATION

\section{BANK}

\begin{tabular}{|c|c|c|c|}
\hline $\begin{array}{l}\text { Loan Account AC } \\
1+\text { loan claim } \\
2 \text { - debt payout }\end{array}$ & $\begin{array}{l}0 \\
+W_{a} L_{a} \\
-W_{a} L_{a}\end{array}$ & $\begin{array}{l}\text { Deposit Account AC } \\
1 \text { + loan deposit from AC } \\
2 \text { - payment to AW } \\
3 \text { + payment from AW } \\
3 \text { + payment from IW } \\
3 \text { - payment to IC } \\
\text { Deposit Account AW } \\
2 \text { + payment from AC } \\
3 \text { - payment to AC }\end{array}$ & $\begin{array}{l}+W_{a} L_{a} \\
-W_{a} L_{a} \\
+W_{a} L_{a} \\
+W_{n} L_{n} \\
-P_{a} C_{a} \\
0 \\
+W_{a} L_{a} \\
-W_{a} L_{a}\end{array}$ \\
\hline $\begin{array}{l}\text { Loan Account IC } \\
1+\text { loan claim } \\
2 \text { - debt payout }\end{array}$ & $\begin{array}{l}0 \\
+w_{n} L_{n} \\
-w_{n} L_{n}\end{array}$ & $\begin{array}{l}\text { Deposit Account IC } \\
1 \text { + loan deposit from IC } \\
2 \text { - payment to IW } \\
3 \text { + payment from IC } \\
3 \text { + payment from AC } \\
3 \text { - payment to IC } \\
\text { Deposit Account IW } \\
2 \text { + payment from IC } \\
3 \text { - payment to IC }\end{array}$ & $\begin{array}{l}+W_{n} L_{n} \\
-W_{n} L_{n} \\
+P_{n} C_{n} \\
+P_{a} C_{a} \\
-P_{n} C_{n} \\
0 \\
+W_{n} L_{n} \\
-W_{n} L_{n}\end{array}$ \\
\hline
\end{tabular}




\section{NON BASICS}

INDUSTRIAL CAPITALIST (IC)

\begin{tabular}{|l|l|l|l|}
\hline Deposit with bank & $+w_{n} L_{n}$ & $1+$ loan debt to bank & \\
1 + loan deposit & $-w_{a} L_{a}$ & & \\
2 - wage payments & $-P_{n} C_{n}$ & \\
3 - payments to $A C$ & $+P_{a} C_{a}$ & & \\
$3^{\prime}+$ sales to AC & $+P_{n} C_{n}$ & & \\
$3^{\prime \prime}+$ sales to IC & & \\
\hline
\end{tabular}

INDUSTRIAL WORKER (IW)

\begin{tabular}{|l|l|}
\hline Deposit with bank & 0 \\
$2+$ wages from IC & $w_{n} L_{n}$ \\
3 - payments to $A C$ & $-w_{n} L_{n}$ \\
\hline
\end{tabular}

